\title{
XXXIII. Observations on Osmoderma and some new Species of Cetoniadæ. By the late Mr. William Bainbridge, Curator to the Entomological Society.
}

[Read March, 1840.]

Observing in Mr. Hope's magnificent collection of Lamellicorn beetles various undescribed insects, I expressed a wish to be allowed to describe some of them; and if the present paper meets with the approbation of the Society I shall gladly attempt other groups, as I feel persuaded, from the rapid increase of the collection above named, it is impossible for one individual to attempt to describe the novelties daily accruing, and I the more readily undertake the task as I am aware that Mr. Hope is actively engaged in describing other groups, as well as employed in finishing the last Fasciculus of the Coleopterist's Manual, which will, I have no doubt, shortly make its appearance.

\section{Osmoderma of Lepeletier and Serville.}

The type of the genus Osmoderma is the Scarabaus Eremita of Linnæus. Messrs. Gory and Perchéron, in their Monograph of Cetoniada, have mentioned only three species.*

\section{OSMODERMa.}

Section 1.-Elytris parum scabris, subrugosis sub lente minutissime punctulatis.

$$
\begin{aligned}
& \text { Sp. 1. Osmod. Eremita .... Linnæus .... E Europe. } \\
& \text { 2. Lremicola .. Knoch ..... N North America. }
\end{aligned}
$$

* [This is hardly correct, for Messieurs Gory and Perchéron (Mon. Cet. p. 77, and pl. 8, fig. 2), in their description of Osmoderma scaber, have confounded two species together, considering them as sexes of one insect; describing as the female a specimen (evidently the one contained in the collection of Mr. Hope from Lee's Cabinet, labelled Africa aquinoxiali, which was sent over to Paris by Mr. Hope for their examination) as distinguished by " l'absence des rebords du chaperon, et par ses carenes dorsales, peu senties; sa couleur, du moins dans l'individu que nous avons sous les yeux, est plus foncée." Their figure 2 is evidently taken from this individual, as it agrees exactly with Mr. Hope's specimen in size and shape. The sexes of the true North American species differ however in the wider form of the clypeus and thorax, both sexes however agreeing together in colour as well as in having the front of the clypeus elevated; one sex moreover has the elytra evidently narrowed in front. Mr. Kirby appears to have described the $\mathrm{Osm}$. scabrum under the name of Trichius (Gymnodus) foveatus in the Fauna Boreali Americana, p. 140, where he has described another species under the name of Trichius (Gymnodus) rugosus.-J. O.W.] 
Section 2. Elytris scabrosis, striato-punctatis.

Sp. 3. Beauvoisii......... Hope ...... Equin. Africa.

4. Scabrum ......... Pal. Beauv... New York.

As there cannot exist a doubt as to the species of the first section, I do not re-describe them. The following descriptions of the two remaining, with their measurements, will sufficiently discriminate them.

Sp. 3. (1.) Osmoderma Beauvoisii, Hope.

Nigrum, clypeo convexo, thorace fortissime punctato seu varioloso, lateribus externe subserratis, lineâ mediâ longitudinali parum impressâ. Elytra thorace multo latiora, depressa, striata, striis fortiter insculptis. Corpus infra nigrum et nitidum.

Long. lin. 9-11, lat. lin. 6 .

I have named this species after Palisot de Beauvois. The locality is equinoctial Africa, and not North America; the specimen in Mr. Hope's collection was contained in the collection of Mr. Lee.

Sp. 4. (2.) Osmoderma scabrum, Pal. de Beauv.

Syn. Trichius scaber, Pal. de Beauv. p. 58, Col. Pl. IV. fig. 2.

Cupreo-æneum seu bronzeum, clypeo valde reflexo, posticè foveato. Thorax hexagonus, crebrissime punctulatus, sulco longitudinale lato fortiter impresso. Elytra depressa thorace parum latiora, striis rugoso-punctatis. Corpus infra bronzeum punctulatum.

Long. lin. 9-10, lat. lin. 5 .

The above description, as well as the locality, point out this as a distinct species; it differs in various other minute points, which it is scarcely necessary to mention, as the species is well known. It has been taken near New York, in tolerable profusion, by Mr. E. Doubleday.

Sp. 3. Gnathocera Iris (Fabricius, Gn. amabilis, Bainbridge, olim).

Forma fere ut Gnath. nigritarse, Hope. Totum corpus supra et infra smaragdinum, nitidum, pedibus roseo-opalino colore micantibus. Caput clypeo emarginato, antennis nigro-piceis, gula aurantiis capillis obsita. Thorax trigonus, antice truncatus, lateribus marginatis, punctis atris sparsim dispositis. Corpus infra opalino-viride, et punctatum. Pedes femoribus 
tibiisque micantibus, roseoque colore tinctis et quasi vermibus erosis.

Long. lin. 10, lat. lin. 4.

Habitat in Sierra Leonâ. In Mus. Dom. Hope.

The head and clypeus are elongate, quadrate, and punctate; the margins are reflexed; the anterior angles rounded, and slightly sinuated in front. Thorax broader than long, more punctate at the sides than on the disc. The lateral margins reflexed, the reflexed margin ending before it reaches the base of the thorax. Elytra not much wider than the thorax, and punctatestriate, each elytron has two elevated and abbreviated ridges. Body beneath punctate. Legs slightly clothed with tawny pubescence, and marked with numerous vermiculate lines.

This fine species is entirely of an emerald green colour, shaded with black. [Vid. Arcan. Ent. pl. 19, fig. 2, and p. 107.]

\section{Sp. 4. Diplognatha nigrita, Bainbridge.}

Totum corpus supra et infra nigrum. Caput clypeo quadrato, dente breve utrinque armato, lateribus elevatis. Thorax hexagonus, variolosus. Elytra thorace parum latiora, antice scabra, postice læviora, in singulo ad apicem tuberculum elevatum et insignitum. Corpus infra nigrum punctatum, pedibus atropiceis.

Habitat in Sierra Leonâ.

The above undescribed species was brought to this country by Mr. Strachan, lately returned to England. I cannot consider any of the insects figured in Messrs. Gory and Perchéron's Monograph to be the same species; it is to be regretted that many of the descriptions of the species in that work are very deficient, and some of the plates are so bad that it is impossible to make out the species intended by those authors. The present species is very closely allied to the Diplognatha variolosa of Latreille.

\section{Sp. 5. Diplognalha holoserica, Bainbridge.}

Totum corpus supra nigrum, thorace subtilissime punctulato, elytrisque striatis, lineis aliquot elevatis, punctis inter strias dispositis. Corpus infra nigrum, nitidum, pubescentiâ aureolâ aspersum. Abdomen lineâ mediâ longitudinale rubrâ impressâ, pedibus ciliatis.

Long. lin. $9 \frac{1}{2}$, lat. lin. $5 \frac{1}{2}$.

Habitat in Sierra Leonâ. 
I have given the name of holoserica, signifying velvety, to this species, as it expresses well the character of the insect, holosericea is quite another word.

The clypeus is quadrate and punctate, with the margins reflexed and slightly produced at the anterior angles. The thorax is hexagonal and very convex, the surface resembling velvet, of a black colour, and punctured. Scutellum rather large. Elytra dull black, with elevated ridges, and striated, the interstices punctate. Body beneath shining black, the breast and legs clothed with tawny hairs.

The above fine species was brought to England by Mr. Strachan.

\section{Sp. 6. Diplognatha rama, Hope's MSS.}

Similis Cet. hebreec, Oliv., at differt. Rufescens, thorace elytris purpureo-variegatis, clypeo rotundato. Corpus infra nigrum et nitidum, sterno rotundato, et rubro. Pectus utrinque maculâ latâ rubrâ insignitum; externis segmentis abdominis femoribusque posticis rubro-maculatis, lateribus quasi vermibus erosis.

Long. lin. $8 \frac{1}{2}$, lat. lin. $4 \frac{1}{2}$.

Habitat in Japonia. In Mus. Dom. Hope.

For the present I range this species under Diplognatha, to which genus it is certainly nearly allied, although I believe no Diplognatha has yet ever been described from the East Indies; I think it right therefore to state the cause of my doubt, and add some other characters. The head and clypeus are quadrate and punctate, with the anterior margin rounded and reflexed, and not sinuated as in Cet. hebraa. The thorax is hexagonal, with the corners rounded. The surface is sparingly punctate at the sides. The elytra are broader than the thorax, and but little attenuated. The entire surface of the insect is of a testaceous red, thickly variegated with bluish black markings. The apex of the sternum is dull red. The sides of the breast, and the apex of the intermediate and posterior femora, together with the sides of the abdomen, are spotted with the same colour.

\section{Sp. 7. Diplognatha pectoralis, Hope's MSS.}

Corpus supra fusco-rubrum; clypeo 2-dentato, pectore infra flavo maculato, segmentis abdominis utrinque flavo-notatis, pedibusque piceis.

Long. lin. $7 \frac{1}{2}$, lat. lin. 4 .

Habitat in Sierra Leonâ. 
This insect is closely allied to Diplognatha; it appears to be a form uniting Campsiura of Mr. Hope and Diplognatha of Messrs. Gory and Perchéron. The following characters distinguish it from both.

The head and clypeus are elongate and quadrate, the sides are elevated and produced into two small teeth at the anterior angles. The thorax is hexagonal, and the spaces between the angles are subsinuate, a few large variolose punctures appearing at the sides; the thorax is depressed and much produced towards the scutellum. The elytra are broader than the thorax, and much narrowed at the apex, with the surface uneven. The shoulders are elevated and impressed, deeply concave near the scutellum, and punctatostriate; the striæ are indistinct and imperfect. The colour above is pitchy red and very glossy ; beneath it is somewhat of a lighter colour. The epimera are yellow, and the breast on each side has a broad yellow spot, with a smaller one near the margin of the elytra. The first four segments of the abdomen are also spotted with yellow. The hexagonal sub-sinuated form of the thorax, and the colours beneath, well characterize this species from any other yet described. It may probably be considered the type of a new genus.

\section{Sp. 8. Stripsipher ambiguus, Hope's MSS.}

Totum corpus supra et infra nigrum pubescentiâ aureolâ aspersum. Caput nigrum, clypeo antice porrecto seu nasuto. Thorax punctatissimus, antice rotundatus, postice subsinuatus, lateribus angulatis. Scutellum magnum, punctulatum. Elytra thorace latiora, parum convexa, lineis quatuor elevatis longis, aliâque abbreviatâ ad marginem positâ. Corpus infra nigrum, pubescentiâ flaveolâ aspersâ.

Long. lin. $6 \frac{1}{2}$, lat. lin. $2 \frac{1}{2}$.

Habitat in Sierra Leonâ.

This remarkable insect at some future time will be the type of a distinct genus, it is closely allied to Stripsipher of Gory, and for the present may be ranged with that genus. It was brought to this country by Lieutenant Sayers.

\section{Sp. 9. Cetonia Withillii, Bainbridge.}

Cuprea, thorace binis maculis albis minutis, fere in medio disci positis, elytrisque flavo-maculatis. Corpus infra roseo-cu- 
preum nitidum, pectore et abdomine variis maculis aspersis, pedibusque cupreis.

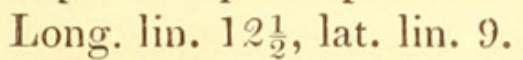

Habitat in Indiâ Orientali.

This magnificent Cetonia was brought to England by Colonel Withill, and I retain the name applied to it, after that indefatigable collector, in Mr. Hope's cabinet.

The body is large and quadrate; the clypeus nearly square, anteriorly reflexed, and slightly punctate. The thorax is convex and rather broader than long, and as narrow as the head in front; it is much dilated and deeply sinuated behind, with two minute white spots near the disc and a small white spot at each posterior angle. The elytra are convex, broad at the base, slightly attenuated, and rounded at the apex; the sutural angles are produced into an acute spine, the sternum being short and rounded. The upper surface of this beautiful Cetonia is of a dark copper colour, with six yellow spots on each elytron, four at the margin and two near the suture. Body beneath of a rich shining copper colour, with the breast and abdominal segments spotted with yellow.

\section{Sp. 10. Cetonia Saundersii, Bainbridge.}

Affinis Cet. alboguttata, Vigors, at differt. Totum corpus supra aurato-viride, alboguttatum; antennis tarsisque nigricantibus. Corpus infra viride, nitidum, segmentis abdominis utrinque albomaculatis.

Long. lin. 8, lat. lin. 4.

Habitat in India Orientali, forsitan e regione Assamensi.

This insect was given to Mr. Hope by W. W. Saunders, Esq., who has named it after him. The following differences distinguish it from the alboguttata of Vigors.

Head and clypeus punctate, with the anterior angles rounded and the margin reflexed. Thorax as long as broad, trigonate and punctate. Elytra broader than the thorax, striate-punctate. Colour shining green, the thorax with eight small round white spots. Epimera green, with a white spot. Elytra golden and brilliant green, with seven white spots on each. Body beneath shining green, very much punctate, with a few white spots. In various other respects this insect differs considerably from the alboguttata of Mr. Vigors, that species being a dull green colour and impunctate, with white spots on the head and clypeus; Cetonia Saundersii is of a shining green and very much punctured, 
the white spots are fewer in number and differently located, and the elytra do not terminate in a spine.

\section{Sp. 11. Amphistoros affinis, Bainbridge.}

Affinis Cet. elate, Fab., at differt. Nigra, thorace lineis tribus albis. Elytris flavis, ad apicem albo-punctatis, anoque utrinque maculâ albâ rotundatâ insignito. Corpus infra nigro-piceum, medio abdominis concolori, lateribus albo-maculatis.

Long. lin. 7, lat. lin. 4 .

Habitat in Sierra Leonâ.

It is with a doubt I describe this as a new species; I shall therefore state at length the difference between what I have named affinis, and the Cetonia elata of Fabricius, and the varians of Messrs. Gory and Perchéron. In markings and in colour it cannot agree with the former, and with regard to varians it is shorter and broader than that species, and differs very considerably in its sculpture and markings; its leading peculiarity is, that the centre of the abdomen is pitchy black, without the usual row of spots. I mention this as I believe it to be a sexual difference, the same variation occurring in the species named elata by Fabricius. It appears, therefore, that this species must be compared with varians of Gory and not with elata; it differs from the former, in the markings of the thorax, in the absence of the two round spots at the apex of the elytra; the podex is also differently marked, having a small round white spot on each side, whereas in varians it is almost entirely white. There is probably another species allied to affinis, which I do not attempt to describe till I ascertain the opinion of those who are competent to judge on the matter. I believe no entomologist has yet mentioned any thing concerning the sexes of this genus.

\section{Stethodesma, Hope.}

Forma Gymnetidis. Clypeo fisso sicut in Lomaptera. Thorax trigonus, antice abrupte truncatus, postice disco protenso ut in Gymnetide. Elytra gradatim basi ad apicem attenuata, medio acuminata. Sternum valde prominens, oblique fissum, apice antice elongato. Pedes anteriores femoribus bispinosis, reliquis inarmatis.

* So named from $\sigma \tau n \theta 0 \delta \xi \sigma \mu \circ \varsigma$, a bandage of the breast. 


\section{Stethodesma Strachani, Hope.}

Totum corpus fere nigrum, marginibus externis rubris. Elytris atris, postice albis punctis insignitis, apicibusque rubris. Corpus infra rubro-piceum, segmentis abdominis duplice serie macularum notatis.

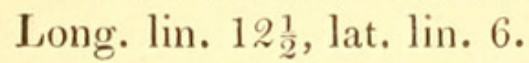

The above remarkable insect is named in honour of $\mathrm{P}$. S. Strachan, Esq., one of the most indefatigable entomologists that ever visited Sierra Leone. As I have formed it into a genus I may, perhaps, be allowed to dilate more fully in English details than I have in the Latin.

Clypeus elongate, smooth, and deeply emarginate in front. Thorax very convex, lateral margins rufous. Scutellum not visible, the base of the thorax being produced into a projecting lobe, as in Gymnetis. Elytra rather broader than the thorax, with indistinct elevated ridges, and five small yellowish white spots near the apex, which is rufous. Body beneath pitchy red. Sternum large, projecting. The abdomen is marked with yellowish white spots; the upper surface of this fine insect of rich black velvet. In size and form it resembles Lomaptera, while in its large epimera it approaches Cetonia, and, as above noticed, the basal lobe of the thorax connects it with Gymnetis; its superficies being like the South American species named Marmorina by Mr. Kirby. 


\section{$2 \mathrm{BHL}$ Biodiversity Heritage Library}

1842. "XXXIII. Observations on Osmoderma and some new Species of Cetoniadæ by The late Mr. William Bainbridge Curator to the Entomological Society." Transactions of the Entomological Society of London 3, 214-221. https://doi.org/10.1111/j.1365-2311.1842.tb03273.x.

View This Item Online: $\underline{\text { https://www.biodiversitylibrary.org/item/48701 }}$

DOI: https://doi.org/10.1111/j.1365-2311.1842.tb03273.x

Permalink: https://www.biodiversitylibrary.org/partpdf/37535

\section{Holding Institution}

Smithsonian Libraries

\section{Sponsored by}

Smithsonian

\section{Copyright \& Reuse}

Copyright Status: Public domain. The BHL considers that this work is no longer under copyright protection.

This document was created from content at the Biodiversity Heritage Library, the world's largest open access digital library for biodiversity literature and archives. Visit BHL at https://www.biodiversitylibrary.org. 